\title{
Relationship of Personality Traits with the Academic Performance of Students: A case study of undergrad students of CBM \& IHM.
}

\author{
SohailMohiuddin Pasha \\ Assistant Professor Institute of Health Management, Dow University of Health Sciences
}

\begin{abstract}
The study has examined the effect of personality traits on the academic performance of students in introductory management course at the undergrad level of business students. The researcher collected data from 100 students from two well recognized business institutes namely; College of Business Management $(C B M)$ and Institute of Health Management (IHM). It has been found that nearly all five traits of personality were found insignificantly correlated with the students' performance academically in the course of study. However, with having no significance it can be inferred that the traits are positively correlated with the grades of students $(r=.151)$. Regression analysis has been done to assess the impact of traits with the students' academic performance.
\end{abstract}

\section{Introduction}

It is commonly observed that the level of getting and processing information varies among students; in this way they show multiple personality traits which in turn reflect on their level of understanding to the information delivered to them; they also express their personal values very differently therefore it is a common opinion that a strong mix of personality traits is very essential for the professional growth and success of people. Researchers have been putting a lot of efforts to identify the factors contributing the impact of students' behaviors on their academic performances, because personality is one of very major variables to know the learning patterns of students (Lawrence, 1997; Myer et al, 1998).

Students' differ from one another in personality traits; the personal values of every individual differ from each other and the way each individual receive and process information also varies, this leads to the level of comprehension of multiple concepts of each individual. Students at their college level are more selective and inclined towards the educational environments that are relevant and suitable with their personalities. Researchers believe the Five Factor Model as the most integrated classification of personality (Digman, 1990; Goldberg, 1992; Witt et al, 2002) and have statistically and reasonably found a major association of professional career and academic achievement with the personality traits (Hogan \& Hogan, 1989; Day \& Silverman, 1989). It is still a dearth to find out the contribution of personality traits on the academic attainment in the Principles of Management course. The scope of this research is basically to know the impact of personality on the academic performance of undergraduate students in Principles of Management course by utilizing Five Factor Model of personality.

\section{Objectives:}

- To examine the relationship between Five Factor Model of Personality (FFM) and students' academic perfor mance in the Management course

- To investigate which particular personality trait envisage Management students' performance in their Principles of Management course.

\section{Previous Studies on Students' Personality types: A Brief}

Still the researchers have not been able to find out a common opinion regarding the structure of Five Factor Personality Model. However the positive aspect of Big Five model is its integrated applicability on multiple techniques and methods to measure personality (John \&Srivastava, 1999). In this way this model is specifically good to conclude the cumulative findings on multiple studies (Barrick\& Mount, 1991). The Big- 5 model of personality was derived from Cattell et al efforts (1970) and took a lot of time to develop after several personality characteristics testing through factor analysis. Norman (1963) did further improvements in this model by selecting 4 Cattellian variables for each of the 5 factors to be used for undergraduate peer scorings leading to factor analysis. The Norman work is realized practically supporting the structure of Big-5 Model. Now the model is generally used by researchers due to its best combination of Cattell's (1970) broad personality characteristics list with the brief list of personality traits given by Eysenck's (1991). The Big-5 factors are given as: 
- Extroversion

- Neuroticism

- Agreeableness

- Conscientiousness

- Openness

However there are several other models used by professionals and researchers but Big-5 model is generally accepted. Further explanation of these factors is given as: Extraversion Individuals with extraversions are mostly positive, lively, chatty, cheerful, enthusiastic and brightly natured (Costa \& McCrae, 1992). They are always ready to socialize with others and keep on searching ways to become happy (H. J. Eysenck\&Eysenck, 1975; Ashton, Lee, \&Paunonen, 1999). It is found that extraversion comprises of two major elements, first is belongingness (associated with relationships) and second is agency (sociable, positive and dominant) (Depue and Collins 1999). It is further argued that optimistic emotions are the basic element extroversion where individuals use to show positive and assertive thinking and expression (Watson and Clark, 1997). Hence it is concluded that extroverts due to their capability of accepting change are likely to be very intelligent and ambitious.

\section{Openness to experience}

Conventional concept for Openness to experience comprises of culture (recognition of different discipline of science and arts with a flexible behavior to the norms, beliefs, moral and values exist in the society) and intellectual ability (the capability of individuals to understand and comprehend) (McCrae \& Costa, 1997). Individuals with high score on openness to experience are found to be inventive, reflective, emotionally and intellectually stable, artistic, dynamic thinker, behaviorally liberal, practical and perceptive in nature (Judge and Bono, 2000; Mc- Crae, 1996; John \&Srivistava, 1999)

\section{Conscientiousness}

As cited by Fiske (1949) and Hogan (1983) conscientiousness is a term used for conformity or dependability. It has found to be a strong relationship with the educational performance so it can be used as an alternative for will to achieve and work (Peabody \& Goldberg, 1989; Digman, 1989). As stated by few researchers (Botwin\& Buss, 1989; John, 1989) conscientiousness individuals are considered to be highly planned, organized and exhibits desirable characteristics like goal orientated and passionate. They are more liable and comprehensive in their performance. As stated by Entwistle\&Tait (1996) Students with high conscientiousness scores are goal oriented, hard working, punctual and organized in their studies. According to Entwistle(1988) highly conscientiousness students are internally motivated and optimistic in their behavior. On the contrast low conscientiousness scored students are found less visionary, careless, anddiverted in their studies.

\section{Agreeableness}

Agreeable individuals are considered to be conflict avoiders, trust worthy, sincere, honest, kind hearted and always value their associations and belongingness; moreover they are the true exhibitors of different behaviors as they are found to be extreme unselfish and shy towards their surroundings (Graziano\& Eisenberg, 1997; Graziano, Jensen-Cambell, \& Hair, 1996). They show a deep concern of others needs to grow and develop and consider contingent rewarding to praise individuals according to their quality of task accomplishment (Bass, 1985, p. 122). Individuals with high scores on agreeableness are observed as an inspirational personality due to their high level of trust and their ability to recognize and concern for others needs(Judge and Bono, 2004).

According to Goldberg (1992) agreeableness is more related with the socialization. Less agreeable students are found to be very agitated and problematic.

\section{Neuroticism}

Neurotic individuals are considering being the negative viewer of the surrounding have capability to show adverse expression of anxiety, distress, culpability and agitation (Costa and McCrae, 1992). Individuals with more effects of neuroticism are likely to express emotional fear on the contrast individuals with low effects are more stable, cool and comfortable. A study conducted by Judge, Erez, Bono and Thoresen (2002) found a very significant relationship of neuroticism with self confidence and self interest both at low level.

Schneiderjan et al (2005), however, observed a significant relation of emotionally stable students with their academic achievement in an online business course. Different studies have been conducted to find a correlation of Big Five personality models with student's academic performance (Costa \& McCrae, 1992). As cited by McKenzie (1989) there is no significant correlation found between neuroticism and academic performance of students however extraversion and higher education achievement of students are explored to be negatively related. According to Masgrave- Marquart, Bromley, and Dalley (1997) very significant relationship of conscientiousness, openness to experience, and neuroticism is found with the students grade point average in a positive manner. 
Hypothesis:

Big Five personality traits are significantly related to students' academic success in an introductory management course.

\section{Methodology}

The research is a descriptive study and analyzed the hypothesis based on the objective of the study. The research instrument selected for the study is a detailed questionnaire comprising of 4 questions for each of the element of Big Five model of personality. The students have rated a total of 20 questions on a 5 points Likert type Scale $(1=$ strongly disagree, $5=$ strongly agree). The measurement of students' academic achievement is based on the students marks range as given in the questionnaire for the selected course of study (marks, 50$59=\mathrm{D}=4,60-69=\mathrm{C}=3,70-79=\mathrm{B}=2,80 \&$ above $=\mathrm{A}=1$ )

Convenience sampling method is adopted by the researcher. The researcher collected data from 100 students from two well recognized business institutes namely; College of Business Management (CBM) and Institute of Health Management (IHM). Students provided information regarding their age, gender, year of study and the Grade they obtained in the selected course of study. The collected data of questionnaire is analyzed using statistical software SPSS 20 version.

Measures:

At the start of the next semester, a questionnaire based on personality inventory was distributed to the undergraduate students of the universities selected for study. The researcher divided the five factor model questionnaire into four questions for each of the personality variables (conscientiousness, agreeableness, neuroticism, extraversion, openness to experience). The respondents were asked to mark on five point likert scale ranging from 1= Strongly Disagree, 5=Strongly Agree for each question.

\section{Academic Achievement Measure:}

As the year of study was 2014, so students' academic grades were considered for the subject of study at the year end, after getting the responses from the personality based questionnaire. Students academic grades were measured as $5=\mathrm{A}, 4=\mathrm{B}, 3=\mathrm{C}, 2=\mathrm{D}$ and $1=\mathrm{E}$.

\section{Data Analysis:}

The research objective was examined by computing Pearson correlations between the FFM domain scores on the one hand and the student grades on the other hand. Next we conducted multiple regression analysis-taking grades as dependent variable, and the scores of five personality traits as independent variables

\section{Results}

Table 1 presents the descriptive statistics of scales and academic achievement. The table shows the mean of students' academic achievement and the means of their personality traits (agreeableness, conscientiousness, openness, extroversion, and neuroticism) and Pearson correlation that shows the relations between the dependent variable (grade) and independent variables (students' personality traits).

Table 1: Descriptive Statistics of Scales and Grade (Academic Achievement) and Pearson Correlation among the variables.

\begin{tabular}{|l|l|l|l|l|l|l|l|l|}
\hline & Mean & SD & Agree & Cons & Open & Extra & Neuro & Grade \\
\hline Agree & 11.23 & 1.68 & 1 & .250 & .496 & .187 & .226 & .557 \\
\hline Cons & 11.14 & 2.12 & .250 & 1 & .218 & .347 & .219 & .402 \\
\hline Open & 10.84 & 1.96 & .496 & .218 & 1 & .237 & .181 & .462 \\
\hline Extra & 10.45 & 2.34 & .187 & .347 & .237 & 1 & .198 & .572 \\
\hline Neuro & 12.25 & 2.36 & .226 & .219 & .181 & .198 & 1 & .486 \\
\hline Grade & 4.32 & .79 & .557 & .402 & .462 & .572 & .486 & 1 \\
\hline
\end{tabular}

Correlation is significant at the 0.05 level (2-tailed)

As per the results all five traits of personality were found insignificant correlation with the students' performance academically. However, having no significance it can be inferred that almost all the traits are positively correlated with the grads of students $(\mathrm{r}=.151)$. Regression analysis has been done to check the impact of traits with the students' performance academically. Table 2 is depicting insignificant level found for the personality variables and students performance.

Table 2:Regression results for Relationships between Personality Traits and Students' Academic Performance:

\begin{tabular}{|l|l|l|l|}
\hline & & \multicolumn{2}{|l|}{ Academic Performance (Grade) } \\
& & T & Sig. \\
\hline & B & & \\
\hline Agreeableness & -0.019 & -0.409 & 0.683 \\
\hline
\end{tabular}




\begin{tabular}{|l|l|l|l|}
\hline Extroversion & -0.008 & -0.201 & 0.841 \\
\hline Neuroticism & -0.031 & -0.746 & 0.457 \\
\hline conscientiousness & 0.036 & 1.075 & 0.285 \\
\hline Openness & 0.029 & 0.836 & 0.405 \\
\hline
\end{tabular}

\section{Discussion}

The development of FFM is a fruitful basis for investigating the personality traits of students with their academic performance in the business courses. In all of the five FFM personality traits, usually agreeableness trait is found to have insignificant weaker relation with the academic performance of students. However in this current study, all of the five traits are observed as insignificant towards the achievement of students in their grades of the course. As cited by McCown and Johnson (1991), extroverts are found to be more into social activities with less study time. As given by Nguyen, Allen \&Fraccastoro (2005), it is found through regression analysis that openness to experience and neuroticism are more vital indicators to assess the student's academic achievement then the agreeableness and conscientiousness.

\section{Implications:}

The personality traits have a vital role towards the development and comprehension of students studying management and other courses that can be measured by their academic grades, may leads to different teaching and training consequences. The traits of personality are showed in the patters of learning concepts that eventually showed in the actions to learn and its output as given by De Raad\&Schouwenburg, 1996. Hence the personality is considered to be a very important tutorial device. The usefulness of personality understanding towards the students gathering and processing knowledge can develop different new actions and strategies to facilitate both the academicians' teachers and students in the areas of business education.

\section{Directions for Future Research:}

The Personality traits have been observed as independent variables towards the assessment of academic achievement of business students at undergrad level. However few other variables such as demographical, social and others can also have impact on both the personality and students achievement academically. Multiple researchers investigated and found the researches on personality as an exploration of different "nature-nurture" "biological-cultural" issues such as the dopamine levels in the body can be reflected through the openness to experience trait of FFM, resulting in creating connection between intelligence quotient and openness to experience as cited by DeYoung, Peterson \& Higgins, 2005. Moreover, further exploration on personality can be taken into consideration to investigate other relationships.

\section{References}

[1]. Barrick, M.R. and Mount, M.K. (1991). The Big Five personality dimensions and job performance: A meta-analysis. Personnel Psychology, 44, 1-26.

[2]. Blickle, G. (1996). Personality traits, learning strategies, and performance European Journal of Personality, 10, 337-352.

[3]. Buchanan, T. (2001). Online implementation of an IPIP Five Factor Personality Inventory, http://users.wmin.ac.uk/buchant/wwwffi/introduction.html, site accessed 2.15. 2004.

[4]. Cattell, R.B., Eber H.W., and Tatsuka, M.M (1970).The handbook of the sixteen-personality factor questionnaire. Champaign, IL: Institute for Personality and Ability Testing.

[5]. Catell, R \& Butcher, H. (1968).The prediction of achievement and creativity. New York: Bobs-Merrill.

[6]. Cooper, S.E., and Miller, J.A. (1991).MBTI learning style-teaching style discongruencies, Educational and Psychological Measurement, 51, 699-707.

[7]. Costa, T and McCrae, R.R.(1992). Normal personality assessment in clinical practice: The NEO Personality Inventory. Psychological Assessment, 4, 5-13.

[8]. Day, D. and Silverman, S. (1989). Personality and Job performance: Evidence of Incremental Validity: Personnel Psychology, 42(1), 25-36.

[9]. DeFruyt\&Mervielde, I. (1996). Personality and interests as predictors of educational streaming and achievement. European Journal of Personality, 10, 405-425.

[10]. De Raad, B. \&Schouwenburg, C. (1996). Personality in learning and education: a review. European Journal of Personality, 10, 303336

[11]. DeYoung, Peterson and Higgins. (2005). Sources of Openness/Intellect: Cognitive and Neuropsychological Correlates of the Fifth Factor of Personality, Journal of Research in Personality, 73: 825-258.

[12]. Digman, J.M. (1990). Personality structure: Emergence of the Five-factor model. Annual Review of Psychology, 41, 417-440.

[13]. Entwistle, N. (1 988). Motivational factors in students' approaches to learning in: Learning strategies and learning styles. In R.R. Schmeck (Ed) New York: Plenum Press.pp. 21-49.

[14]. Entwistle, N \&Tait, H. (1996). Approaches and study skills inventory for students. Center for Research on Learning and Instruction.University of Edinburgh.

[15]. Eysenck, H.J. (1967). The Biological basis of personality. New York: Springfield.

[16]. Eysenck, HJ. (1991). Dimensions of personality: criteria for a taxonomic paradigm. Personality and Individual Differences, 12: 773 90.

[17]. Goldberg, L.R. (1992). The Development of makers for the big five-factor structure, Psychological Assessment, 4, $26-42$.

[18]. Hogan, J. \& Hogan, R (1989).How to measure employee reliability. Journal of Applied Psychology, 74(2), 273-279. 
[19]. Hogan, T., \& Hogan, J., \& Roberts, W. (1996).Personality measurement and employment decisions. American Psychologist, 51, 469-477.

[20]. Hogan.(1996). A psychoanalytic perspective on the five-factor model of personality. In J.S. Wiggins (Ed.), the five-factor model of personality (pp. 163-179). New York: Guildford Press.

[21]. Howard, J \& Howard, M. (1998).An introduction to the five-factor model of personality for human resource professionals. Available on: www.centacs.com/quik-pt3.htm, site accessed 7.6.1999.

[22]. Kline, P. (1977). Personality and learning.In Howe, M. (Ed.), Adult Learning.Chichester: Wiley.

[23]. Karen, K; Thisjs M; Schakel, L (2002).The relationship of emotional intelligence with academic intelligence and the Big- Five, European journal of Personality, vol. 16, number 2, March/April.

[24]. Lawrence, G. (1997). Looking at type and learning styles. Gainesville, FL: Center for Application of Psychological Type.

[25]. McCare, R \& Costa, T. (1996). Toward a new generation of personality theories: theoretical contexts for the five-factor model. In J.S. Wiggins (Ed.) The Five factor Model of Personality: Theoretical perspectives, New York: Guilford Press. Pp. 51-87.

[26]. McCown, W \& Johnson, J (1991).Personality and chronic procrastination by university students during an academic examination period. Personality and Individual Differences, 12(5), 413-415.

[27]. McKenzie (1989). Neuroticism and academic achievement: The Fureaux factor. Personality and Individual Differences, 10, 509515 .

[28]. Mount, M \&Barrick, M (1995). The Big five personality dimensions: Implications for research and practice in human resource management. Research in Personnel and Human Resource Management, 13, 153-200.

[29]. Myers, I.B., McCauley, M.H., Quenk, N.L \& Hammer, A.L (1998). MBTI manual: A guide to the development and use of MyersBriggs Type Indicator (3rd Ed.). Palo Alto, CA: Consulting psychologists Press.

[30]. Musgrave- Marquart, D., Broomley, S.P., and Dalley, M.B. (1997).Personality, academic attribution and substance use as predictors of academic achievement in college students. Journal of Social Behavior and Personality, 12, 501-511.

[31]. Nguen, N.T, Allen, L.C., and Fraccastoro, K. (2005). Personality predicts academic performance: Exploring the moderating role of gender, Journal of Higher Education Policy and Management 27, 105-127

[32]. Norman, W.T. (1963). Toward an adequate taxonomy of personality attributes: Replicated factor structure in peer nomination personality ratings. Journal of Abnormal and Social Psychology, 66, 574-583.

[33]. Witt, L.A \&Barrick, M, Burke, L., \& Mount, M. (2002).The interactive effects of conscientiousness and agreeableness on job performance. Journal of Applied Psychology, vol. 87, No.1, 164-169.

[34]. Schniederjan, Marc J; Kim, Eyong B; (2005), Relationship of student undergraduate achievement and personality characteristics in a total web-based environment: An empirical study, Journal of Innovative Education, vol 3, number 2; PP $205-221$. 